Bangladesh J. Genet Pl. Breed., 21(1): 43-48, 2008

\title{
IN VITRO PLANT REGENERATION OF SOYBEAN (Glycine max L.) FROM HYPOCOTYL
}

\author{
S. M. H. Kabir, M. S. Ali ${ }^{1}$ and M. K. Islam \\ Department of Biotechnology \\ Bangladesh Agricultural University \\ Mymensingh 2202, Bangladesh
}

\begin{abstract}
The Experiment was conducted to establish an efficient plant regeneration protocol from hypocotyl sections of soybean. Callus initiation, shoot and root development were observed by using different concentrations and combinations of growth regulators. The best result for callus induction was observed in MS medium supplemented with 1.5 $\mathrm{mg} / \mathrm{l}$ Kinetin and $2.0 \mathrm{mg} / \mathrm{l}$ NAA. The calli were transferred to shoot induction medium. The best shoot induction occurred in the medium containing $3.0 \mathrm{mg} / \mathrm{l} \mathrm{BAP}$ and $0.5 \mathrm{mg} / \mathrm{l}$ NAA. The elongated shoots developed roots on MS medium supplemented with different IBA concentrations where $1.5 \mathrm{mg} / \mathrm{l}$ IBA was the best for root development. Plantlets with a well developed root system were transplanted in plastic container with a soil mixture of cowdung and fine sand. Plantlet survival rate was $70 \%$. Through this experiment, a general suitable regeneration protocol from hypocotyls of soybean has been developed which can potentially be used for micropropagation and future transformation research in soybean.
\end{abstract}

Key words: Soybean, regeneration, hypocotyls, explant.

\section{INTRODUCTION}

Soybean (Glycine max L.) is an important crop of the family Leguminosae, which is grown all over the world. It is the major source of edible oil and plant protein (Bonacin et al., 2000). Although soybean was introduced in Bangladesh a long time ago, no proper attention has so far been given for its improvement. Now a days, genetic transformation of plants has become routine, permitting the introduction of desirable characteristics from other organisms that would not be possible by conventional breeding. The success of soybean transformation has been limited due to the low efficiency of regeneration and transformation methods (Ping et al., 2004). Due to the importance of the crop, however, researchers have attempted to develop effective methods using a variety of tissue culture systems. Tissues commonly used for regeneration purpose were cotyledonary nodes (Barwale et al., 1986), primary leaves of seedlings (Wright et al., 1987), hypocotyl and epicotyl sections (Cristia and Cosima, 1992) and leaves (Settu and Ranjithahumari, 1999). Hypocotyl is one of the tissues of choice for plant genetic manipulations. It is quick and convenient to obtain and is possible to homogenize the physiological state of the tissue in terms of its age.

\footnotetext{
${ }^{1}$ Lab In-charge, Biotech Bangladesh Limited, Rajendrapur, Gazipur, Bangladesh
} 


\section{MATERIALS AND METHODS}

The present research work was carried out in Biotechnology Laboratory of the department of Biotechnology, Bangladesh Agricultural University, Mymensingh, during the period from August 2004 to May 2005. Soybean seeds cv. $\mathrm{G}_{2}$ (Bangladesh Soybean-4) were collected from Soybean and Oilseed Laboratory, Bangladesh Agricultural University, Mymensingh. Seeds were germinated occurred on MS (Murashige and Skoog, 1962) medium. For callus induction and maintenance, MS medium was used with different combinations of NAA $(0.0,1.0,1.5$ and $2.0 \mathrm{mg} / \mathrm{l})$ and Kinetin $(0.0,1.0,1.5$ and $2.0 \mathrm{mg} / \mathrm{l})$ supplementation. MS medium supplemented with NAA $(0.5 \mathrm{mg} / \mathrm{l})$ and BAP $(0.0,1.0,2.0$ and $3.0 \mathrm{mg} / \mathrm{l}$ ) was used for shoot induction. For root formation from shoots different concentrations of IBA $(0.0,1.0,1.5,2.0$ and $3.0 \mathrm{mg} / \mathrm{l})$ were added to MS medium. To ensure aseptic condition under in vitro, all instruments, glasswares, and culture media were sterilized by autoclaving. All inoculations were carried out under laminar airflow cabinet.

Soybean seeds were washed in tap water and then surface sterilized with $70 \%(\mathrm{v} / \mathrm{v})$ ethanol for one min and then rinsed with sterile distilled water. Afterwards the seeds were soaked in $0.1 \% \mathrm{HgCl}_{2}$ containing 2 drops of Tween- 20 per $100 \mathrm{ml}$ solution, for 12 minutes, followed by three rinses in sterilized distilled water. The surface sterilized seeds were then placed in test tubes containing $12 \mathrm{ml}$ MS medium. The test tubes were placed in the culture room in complete darkness at $25 \pm 2^{\circ} \mathrm{C}$ and $70 \%$ relative humidity. Seeds were germinated in 10-12 days. The hypocotyls of 7 days old seedlings were cut into small pieces which were used as explants. Four explants were incubated per petridish. The dishes with explants were inoculated under complete darkness at $25 \pm 2^{0} \mathrm{C}$ for a week after which incubates were kept under $12 \mathrm{~h}$ photoperiod regime of $30 \mu \mathrm{mol} \mathrm{m}^{-2} \mathrm{~s}^{-1}$ provided by white florescent tubes. Callus initiated after 16-20 days of explants incubation. The developed calli were also kept under $12 \mathrm{~h}$ photoperiod at $25 \pm 2^{\circ} \mathrm{C}$. The callus is subcultured onto fresh callusing medium periodically. Six to seven weeks after inoculation, the calli attained a size of about $20-25 \mathrm{~mm}$ in diameter and were transferred to shoot induction medium. When the shoots grew about 2$3 \mathrm{~cm}$ in length, they were subcultured on freshly prepared root induction medium. Rooted plantlets were gently washed out with running water to remove agar and medium from the roots. The plantlets with well developed root system were transplanted to small pots containing previously autoclaved garden soil, sand and cow dung at the ratio of 1: 1: 1 . Immediately after transplantation, the plants along with pots were kept in diffused sunlight of the controlled environment with proper temperature and humidity in the growth room. Data were collected on the effect of different treatments of different parameters. Such as days required for callus induction, callus per petridish, callus weight $(\mathrm{g})$, days required for shoot induction, percent shoot induction, shoot length $(\mathrm{cm})$, days required for rooting, percent developed roots, roots per shoots and root length $(\mathrm{cm})$. The experiment was arranged Completely Randomized Design (CRD) and data were statistically analyzed by the statistical package MSTAT-C and Microsoft Excel whenever applicable. The analysis of variance was performed and means were compared by Ducan's Multiple Ramge Test (DMRT) at 5\% level of probability for interpretation of results (Gomez and Gomez, 1984).

\section{RESULTS AND DISCUSSION}

The present research work was conducted to standardize a protocol for in vitro regeneration of soybean from hypocotyl explant. The results of in vitro plant regeneration are discussed. 
Callus induction: After incubating a week in culture, a change of the explants in size and shape was evident followed by callusing. Explants were yellow green in color that changed to brownish green at later stage (Plate A-E). Days required for callus induction varied with Kinetin and NAA combination. The least days required for callus induction was 15.75 days with a combination of $1.5 \mathrm{mg} / \mathrm{l} \mathrm{Kinetin}+2.0 \mathrm{mg} / \mathrm{l}$ NAA (Table 1). Days required for callus induction decreased with increasing the concentration of NAA. Application of NAA alone can induce callus more quickly than combined use of NAA with kinetin. Hormone combinations and concentrations showed significant variation in callus induction ability. Settu and Ranjithakumari (1999) reported callus induction in soybean within 7 days of incubation. Jang et al. (2001) reported callus induction after 10-14 days of incubation. The longer duration in this experiment might be because of the genotypic difference and growth regulator type.

Table 1. Effect of NAA \& Kinetin on callus formation

\begin{tabular}{cccc}
\hline $\begin{array}{c}\text { NAA + Kinetin } \\
(\mathrm{mg} / \mathrm{l})\end{array}$ & $\begin{array}{c}\text { Days required } \\
\text { for callus induction }\end{array}$ & $\begin{array}{c}\text { Callus/ } \\
\text { Petridish }\end{array}$ & $\begin{array}{c}\text { Callus } \\
\text { weight }(\mathrm{g})\end{array}$ \\
\hline $0.0+0.0$ & $0.00 \mathrm{k}$ & $0.00 \mathrm{~h}$ & $0.00 \mathrm{~h}$ \\
$0.0+1.0$ & $28.7 \mathrm{~b}$ & $1.00 \mathrm{fg}$ & $0.17 \mathrm{~g}$ \\
$0.0+1.5$ & $27.75 \mathrm{c}$ & $1.25 \mathrm{ef}$ & $0.25 \mathrm{f}$ \\
$0.0+2.0$ & $30.25 \mathrm{a}$ & $0.75 \mathrm{gh}$ & $0.22 \mathrm{f}$ \\
\hline $1.0+0.0$ & $0.00 \mathrm{k}$ & $0.00 \mathrm{~h}$ & $0.00 \mathrm{~h}$ \\
$1.0+1.0$ & $23.25 \mathrm{~d}$ & $1.50 \mathrm{e}$ & $0.39 \mathrm{~d}$ \\
$1.0+1.5$ & $22.25 \mathrm{e}$ & $2.25 \mathrm{~cd}$ & $0.35 \mathrm{de}$ \\
$1.0+2.0$ & $23.75 \mathrm{~d}$ & $1.50 \mathrm{e}$ & $0.39 \mathrm{~d}$ \\
\hline $1.5+0.0$ & $0.00 \mathrm{k}$ & $0.00 \mathrm{~h}$ & $0.00 \mathrm{~h}$ \\
$1.5+1.0$ & $20.50 \mathrm{f}$ & $2.50 \mathrm{~cd}$ & $0.52 \mathrm{~b}$ \\
$1.5+1.5$ & $19.50 \mathrm{~g}$ & $2.75 \mathrm{c}$ & $0.48 \mathrm{c}$ \\
$1.5+2.0$ & $21.50 \mathrm{e}$ & $2.25 \mathrm{~cd}$ & $0.43 \mathrm{c}$ \\
\hline $2.0+0.0$ & $0.00 \mathrm{k}$ & $0.00 \mathrm{~h}$ & $0.00 \mathrm{~h}$ \\
$2.0+1.0$ & $17.75 \mathrm{i}$ & $3.25 \mathrm{ab}$ & $0.59 \mathrm{ab}$ \\
$2.0+1.5$ & $\mathbf{1 5 . 7 5 j}$ & $\mathbf{3 . 7 5 a}$ & $\mathbf{0 . 6 5 a}$ \\
$2.0+2.0$ & $18.75 \mathrm{~h}$ & $3.00 \mathrm{bc}$ & $0.54 \mathrm{~b}$ \\
\hline
\end{tabular}

Significant variation was observed in the effect of Kinetin and NAA on the number of callus/petridish. Number of callus/petridish was 3.75 with $1.5 \mathrm{mg} / \mathrm{l} \mathrm{Kinetin}$ and $2.0 \mathrm{mg} / \mathrm{l}$ NAA. The lowest number of callus/petridish was found when NAA was omitted from the medium. Number of callus increased with increasing concentration of Kinetin. However, addition of either of them increased the efficacy and a combined application maximized the callus initiation potentiality. These findings were partially supported by Liu et al. (1997).

Callus weight varies with different factors like explants and different concentrations of growth regulators. The highest callus weight $(0.65 \mathrm{~g})$ was found with the concentration of $1.5 \mathrm{mg} / \mathrm{l} \mathrm{Kinetin}+2.0 \mathrm{mg} / \mathrm{l} \mathrm{NAA}$. The lowest callus weight $(0.13 \mathrm{~g})$ was found with the concentration of $1.0 \mathrm{mg} / \mathrm{l} \mathrm{Kinetin}$ alone (Table 1). It was evident that the combination of 2.0 $\mathrm{mg} / \mathrm{l} \mathrm{NAA}$ and $1.5 \mathrm{mg} / \mathrm{l}$ Kinetin in MS medium performed best for callus induction. This result was partially supported by Settu and Ranjithahumari (1999). Liu et al. (1997) reported that $2.0 \mathrm{mg} / \mathrm{l} \mathrm{NAA}$ and $1.0 \mathrm{mg} / \mathrm{l} \mathrm{Kinetin} \mathrm{was} \mathrm{best} \mathrm{for} \mathrm{callus} \mathrm{induction.}$ 
Shoot induction from callus: The calli were transferred to shoot induction medium to induce shoot. It was evident that hormonal treatments had influence on days required for shooting. The least number of days required for shoot induction was 32.50 when BAP concentration was 3.0 $\mathrm{mg} / \mathrm{l}$ followed by 34.25 days at $4.0 \mathrm{mg} / \mathrm{l} \mathrm{BAP}$ (Table 2). No shoots regenerated when the medium lacked of BAP.

Table 2. Effect of different concentrations of BAP with $0.5 \mathrm{mg} / \mathrm{l}$ NAA on shoot induction

\begin{tabular}{|c|c|c|c|}
\hline $\mathrm{BAP}(\mathrm{mg} / \mathrm{l})$ & $\begin{array}{r}\text { Days required for shoot } \\
\text { induction }\end{array}$ & $\%$ Shoot Induction & Shoot Length $(\mathrm{cm})$ \\
\hline 0.0 & $0.00 \mathrm{e}$ & $0.00 \mathrm{e}$ & $0.00 \mathrm{~d}$ \\
\hline 1.0 & $38.25 \mathrm{a}$ & $12.5 \mathrm{~d}$ & $1.15 \mathrm{c}$ \\
\hline 2.0 & $35.75 b$ & $18.75 \mathrm{c}$ & $1.8 \mathrm{~b}$ \\
\hline 3.0 & 32.50d & $37.5 a$ & $3.05 a$ \\
\hline 4.0 & $34.25 \mathrm{c}$ & $31.5 \mathrm{~b}$ & $1.98 \mathrm{~b}$ \\
\hline
\end{tabular}

BAP exhibited significant influence on the percentage of shoot induction (Table 2). The highest percentage (37.50) was observed in $3.0 \mathrm{mg} / \mathrm{l} \mathrm{BAP}+0.5 \mathrm{mg} / \mathrm{l} \mathrm{NAA}$ and the lowest percentage of shoots/explant (12.50) was found with the concentration of $1.0 \mathrm{mg} / \mathrm{l} \mathrm{BAP}+$ $0.5 \mathrm{mg} / \mathrm{l} \mathrm{NAA}$. No shoots formed when BAP was omitted from medium.

The length of shoots was also influenced with different concentrations of BAP. BAP at $3.0 \mathrm{mg} / \mathrm{l}$ gave the highest shoot length $(3.05 \mathrm{~cm})$ with $0.5 \mathrm{mg} / \mathrm{l} \mathrm{NAA}$ (Table 2). The lowest shoot length was found in $1.0 \mathrm{mg} / \mathrm{l}$ of BAP $+0.5 \mathrm{mg} / \mathrm{l} \mathrm{NAA}$. The results indicated that there was a sharp increasing trend in shoot length with the increase of BAP concentration up to $3.0 \mathrm{mg} / \mathrm{l}$ and thereafter decline.

Considering all the parameters for shoot induction, it was evident that BAP concentrations 3.0 $\mathrm{mg} / \mathrm{l}$ performed better in combination with $0.5 \mathrm{mg} / \mathrm{l}$ NAA. Kim et al. (2001) observed shoot induction on $1.0 \mathrm{mg} / \mathrm{l} \mathrm{BAP}$ alone.

Root development: IBA was used for root development. IBA significantly influenced the days required for rooting. Minimum days (30.25 days) were needed when the concentration of IBA was $1.5 \mathrm{mg} / \mathrm{l}$ (Table 3). No roots were formed without these hormones. This contradicts with the reports of other plants where rooting was evident on growth regulator free medium.

Table 3. Effect of IBA concentrations on root formation of soybean

\begin{tabular}{ccccc}
\hline IBA (mgl) & $\begin{array}{c}\text { Days required } \\
\text { for rooting }\end{array}$ & $\begin{array}{c}\text { \% Shoot } \\
\text { developed roots }\end{array}$ & Roots/shoot & $\begin{array}{c}\text { Root length } \\
(\mathrm{cm})\end{array}$ \\
\hline 0.0 & $0.00 \mathrm{~d}$ & $0.00 \mathrm{e}$ & $0 \mathrm{e}$ & $0.00 \mathrm{c}$ \\
1.0 & $33.25 \mathrm{~b}$ & $12.31 \mathrm{~d}$ & $6.5 \mathrm{~b}$ & $1.63 \mathrm{~b}$ \\
1.5 & $\mathbf{3 0 . 2 5 c}$ & $\mathbf{3 7 . 5 0 a}$ & $\mathbf{8 . 2 5 a}$ & $\mathbf{2 . 9 5 a}$ \\
2.0 & $32.25 \mathrm{~b}$ & $31.00 \mathrm{~b}$ & $5.25 \mathrm{c}$ & $\mathbf{2 . 1 8 a}$ \\
3.0 & $35.50 \mathrm{a}$ & $18.75 \mathrm{c}$ & $2.5 \mathrm{~d}$ & $1.23 \mathrm{~b}$ \\
\hline
\end{tabular}


The highest percentage of rooting (37.50) was observed with $1.5 \mathrm{mg} / \mathrm{l}$ IBA. The results indicated that explants showed an increasing trend in rooting percentage with the increase of IBA concentration up to $1.5 \mathrm{mg} / \mathrm{l}$ and thereafter the percentage declined (Table 3). A significant difference was recorded on the number of roots/shoot due to the effect of IBA. The highest roots/shoot (8.25) was recorded with $1.5 \mathrm{mg} / \mathrm{l} \mathrm{IBA}$. Kim et al. (2001) observed 8.0 roots /shoot with $1.5 \mathrm{mg} / \mathrm{l}$ IBA.
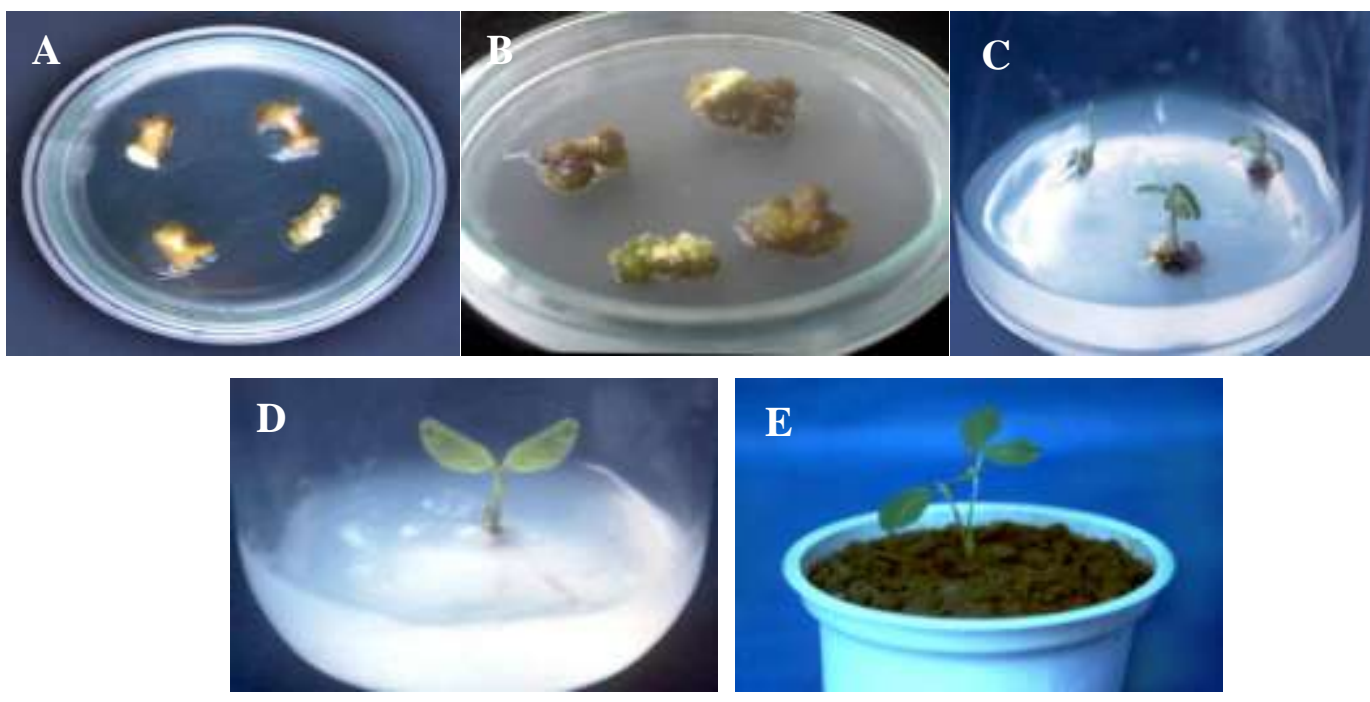

Figure 1. Calli induced from hypocotyl explants of soybean at (A) 25 DAI (Days after inoculation) and (B) 35 DAI. (C) Shoot regeneration from calli. (D) Root development from shoots in MS $+1.5 \mathrm{mg} / \mathrm{l}$ IBA. (E) A regenerated soybean plantlet established in pot.

Variation in root length was influenced considerably by different concentrations of IBA used. IBA at $1.5 \mathrm{mg} / \mathrm{l}$ gave the highest root length $(2.95 \mathrm{~cm})$. The lowest $(1.23 \mathrm{~cm})$ root length was obtained with $3.0 \mathrm{mg} / \mathrm{l} \mathrm{IBA}$. No rooting response took place in hormone free media. Yuan et al. (2001) also observed root induction on IBA supplemented medium. Liu et al. (1998) observed root formation MS medium with $2.0 \mathrm{mg} / \mathrm{l} \mathrm{IBA}$.

Transplantation: The plantlets with well-developed root system were transplanted to small pots. The survival rate of the transplanted plantlets was $70 \%$. The present study describes an efficient but simple protocol for plant regeneration of soybean which could be useful for improving the soybean cultivars of Bangladesh using different biotechnological approaches.

\section{REFERENCES}

Barwale, U.B., H.R. Kerns and J.M. Widholm. 1986. Plant regeneration from callus cultures of several soybean genotypes via embryogenesis and organogenesis. Planta, 167 : 473481.

Bonacin G A, Mauro A O, Oliveira1 R C \& Perecin D. 2000. Induction of somatic embryogenesis in soybean: Physicochemical factors influencing the development of somatic embryos. Genet. Mol. Biol. 23(4):865-868. 
Cristia, V. and D.Cosma. 1992. Studies on the reactivity of different soybean explants types (Glycine max L. Merr.) to in vitro culture conditions. Revue Roumaine de Biologie Serie de Biologie Vegetale, 37: 73-81.

Jang G W, Park R D \& Kim K S. 2001. Plant regeneration from embryogenic suspension cultures of soybean (Glycine max L. Merrill). J. Plant Biotech. 3(2):101-106.

Kim H K, Park H K, Park M S \& Ye U D. 2001. Effects of auxins and cytokinins on organogenesis of soybean Glycine max L. J. Plant Biotech. 3(2):95-100.

Liu Z H, Wang W C \& Yan S Y. 1997. Effect of hormone treatment on callus formation and endogenous indole-acetic acid and polyamine contents of soybean hypocotyl cultivated in vitro. Bot. Bull. Acad. Sin. 38: 171-176.

Liu Z H, Wang W C \& Yan S Y. 1998. Effect of hormone treatment on root formation and endogenous indole-3-acetic acid and polyamine levels of Glycine max cultivated in vitro. Bot. Bull. Acad. Sin. 39: 113-118.

Murashige T \& Skoog F. 1962. A revised medium for rapid growth and bioassays with tobacco tissue culture. Physiol. Plant 15:473-497.

Ping, W., W. Gang, J.I. Jing and W.U. Ying. 2004. A novel system for proliferation, maintenance and plantlet germination from somatic embryo of soybean. Acta Botanica Sinica., 46 (2): 154-158.

Settu A \& B D Ranjithakumari. 1999. In vitro plant regeneration from leaf explants of soybean \{Glycine $\max$ (L.) Merr.\}. Plant Tissue Cult. 9(1): 11-16.

Wright M S, Ward D V, Hinchee M A, Carnes M G \& Kaufman R J. 1987. Regeneration of soybean (Glycine max L. Merr.) from cultured primary leaf tissue. Plant Cell Rep. 6:8389.

Yuan Y, Liu D P, Zheng P H, Xu W J and Li H L. 2001. Study on plant regeneration from soybean culture. Soybean Sci. 20(1):9-13. 